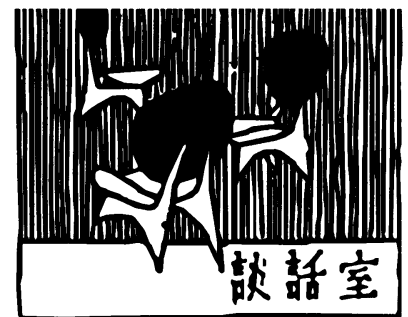

\section{日本学術会議の新体制と 結晶学研究連絡委員会}

\author{
東京I業大学 佐々木 聡
}

本年 10 月 1 日から新しい体制での日本学術会議が発足 した。このため, 2006 年 9 月までの予定でスタートしたH 本学術会議の第 19 期は 1 年短縮され, この9月 30 日をも って終了した．国際結晶学連合 IUCr (International Union of Crystallography）に対する甘本側空口が，日本学術会議 (結晶学研究連絡委員会; Japanese National Committee) であり大きな影響を受けるため，その経緯について報告 する.

まず，日本学術会議の新たな体制について簡単に述べ る. 新しい体制は, 会員 210 名, 連携会員 2,000名程度で 構成され, 現在の会員および研連委員の数とあまり变わ らないようにみえるが, 会員の選出方法が大幅に変更と なった. 初回の会員は, 学術会議の選考委員会により選出 される. 登録学術研究网体などからの推薦や選考委員会 の選定で候補者名簿が作成され，領域ごとに専門家が第 一次審査をし，その結果をもとに選考委員会が 210 名を選 んだ. 第 19 期とは大半が入れ替わり，例えば，現在の第 4 部会員 30 人のうち, 次期も会員となる人は 2 名のみとの ことである. 2 回目以降の会員選出は, co-optationの理念 に基づき，学術会議が自ら会員を選出することになって いる.また，連携会員の選出にも co-optationの理念が用い られこれまでの研究連絡委員会委員の選出とは大幅に 異なったものになる，すなわち，会員同様に，学術会議が 自ら連携会員を選ぶことになっている．最初の連携会員
の半数は 10 月末までに, 残りの半数は来年 3 月末までに, それぞれ選考委員会により選出される予定である.

従来の 7 部構成が 3 部制になるのに呼応して, 第 19 期 に173 あった研究連絡委員会は30の分野別委員会に再編 される(表 1). 第 19 期の結晶学研連は新体制下では化学 委員会 (分野別委員会) の中に分類されている. 必要に応 じて分野別委員会の下に分科会を設置できる，および，複 数の分野別委員会にまたがる分科会を設置できるとされ ているが，すべては，10月に発足する新組織が決めるこ とであり，現在のところ不明である，なお，日本学術会議 の常置委員会として, 分野別委員会以外に機能別委員会が 設置されることになっている. 機能別委員会には, 企画委 員会, 科学者委員会, 科学と社会委員会, 国際委員会およ び選考委員会の5つが提案されている.IUCrは, 47 ある国 際学術付体の1つとして日本学術会議で認知されている. したがって, 分野別委員会とは別に, 新体制の国際委員会 の下の国際会議主催等検討分科会に, 国際対応の「IUCr 小 分科会」が設置される予定である. 移行前の計画によると, 分野別委員会と国際対応の小分科会は, 明らかに二重構造 になっている.

8 月 12 日開催の結晶研連の委員会において, (1) 結晶学 としては複数の分野別委員会にまたがる分科会の設置を 目指すこと, (2) IUCr 小分科会は IUCr関連のみ（場合に よると国際会議のみ) を取り扱うことになるため, 結晶研

表1日本学術会議に設置される 30 の分野別委員会の一覧

\begin{tabular}{|c|c|c|}
\hline 語学·文学委員会 & 基礎生物学委員会 & 数学委員会 \\
\hline 哲学委員会 & 応用生物学委員会 & 物理学委員会 \\
\hline 心理学 - 教育学委員会 & 農学基礎委員会 & 地球惑星科学委員会 \\
\hline 社会学委員会 & 生産農学:委員会 & 情報学:委員会 \\
\hline 史学委員会 & 基礎医学委員会 & 化学委員会 \\
\hline 地域研究委員会 & 臨床医学委員会 & 総合I学委員会 \\
\hline 法学委員会 & 健康 - 生活科学委員会 & 機械工学委員会 \\
\hline 政治学委員会 & 㐘学委員会 & 電気電子丁学委員会 \\
\hline 経济学委員会 & 薬学委員会 & t:木工学·建築学委員会 \\
\hline 経営学委員会 & 材料工学委員会 & \\
\hline
\end{tabular}

環境学委員会 
連が取り扱ってきた事柄を網羅できないこと，(3) 新しく 組織される化学委員会に今後の対応をお願いする必要が あること, を確認し, 9 月 14 日に臨時の研連委員会十結 晶成長専門委員会の合同委員会を開催し, 申し送り事項 を作成することとした。

9 月 14 日の結晶学結晶成長学合同委員会において, 以 下の 5 項目の申し送り事項を作成し, 9 月 16 日開催の第 4 部会に提出した。要望については第 4 部会でまとめた後 に, 次期会員等の関係者に送付することになった。

(1) 新分科会設置の要望. 現在の結晶学研究連絡委員会 および結晶成長専門委員会の領域で, 新分科会を設置し てくれるよう要望した. 化学分野別委員会を中心に, 物 理, 上学, 生命科学, 医学など複数の分野別委員会にまた がる分野横断型の新「結晶」分科が望ましく, かつ, 国際 学術団体対応の新 IUCr 分科会を兼ねる必要がある. また, 結晶成長学の国際組織であるIOCG (International Organization for Crystal Growth) に対応する国内団体も 必要である。

（2）広領域の理学系新分野別委員会 (例えば総合理学 委員会) 設置の要望. 第 19 期第 4 部会として, 総合理学委 員会の設置を要望するようお願いした。

(3) 結晶成長学の国際組織 IOCGへの対応と専門的組織 設置の要望.
(4) IUCr2008に対する日本学術会議共同主催の要請. 日 本学術会議の国際対応の中に, IUCr2008 国際結晶学連合 大阪大会を明確に含めることを要望した. また, IUCr2008 に合わせて 2008 年に, IUCrの 60 周年記念シンポジウム を日本で開催できるよう要請した。

（5）大型施設に係わる問題の専門的審議. 第 19 期で結 晶研連は物理研連などと歩調を合わせ, SPring-8の利用 料金問題を, 先端的大型研究施設での全国共同利用のあり 方という視点で検討した。これは第 4 部提言となり，学術 会議会長のコメントも出された. 今後, フォトンファクト リー, J-PARCその他の既存大型施設のみならず, 新設の 大型施設でも重要な問題になるので, 学術会議として大所 高所に立った議論・提言を継続することを要望した.

以上の申し送りを行ったが, 新しい委員会の行方は現時 点では不明である. 国際対応空口となる国際委員会下の IUCr 小分科会の動向については, 10 月初旬には明らかに なると思われる、いずれにしても，新しい組織を作るには 最初が肝心であり, 第 19 期結晶研連は, 委員間で今後も連 絡を密にとりながら新委員会への道筋をつけたいと考え ている. ぜひ, 結晶学会会員の皆様にも, ご協力をお願い したい. 